University of Miami Law School University of Miami School of Law Institutional Repository

2011

\title{
Helping Haiti in the Wake of Disaster: Law Students as First Responders
}

Melissa Gibson Swain

University of Miami School of Law, mswain@law.miami.edu

JoNel Newman

University of Miami School of Law, jnewman@law.miami.edu

Follow this and additional works at: https://repository.law.miami.edu/fac_articles

Part of the Immigration Law Commons, and the Legal Education Commons

\section{Recommended Citation}

Melissa Gibson Swain and JoNel Newman, Helping Haiti in the Wake of Disaster: Law Students as First Responders, 6 Intercultural Hum. Rts. L. Rev. 133 (2011).

This Article is brought to you for free and open access by the Faculty and Deans at University of Miami School of Law Institutional Repository. It has been accepted for inclusion in Articles by an authorized administrator of University of Miami School of Law Institutional Repository. For more information, please contact library@law.miami.edu. 


\title{
HELPING HAITI IN THE WAKE OF DISASTER: LAW STUDENTS AS FIRST RESPONDERS
}

\author{
MElissa Gibson SWAIN ${ }^{*}$ AND JONEL NEWMaN ${ }^{+}$
}

On January 12, 2010, a devastating and catastrophic 7.0 magnitude earthquake struck Haiti. In Miami, the concern and desire to help was palpable. Many of our law school clinic students tried to find a way to go to Haiti to help in any way they could. They peppered us with questions about how they might get to Haiti to assist in relief efforts. A week after the earthquake, and only a day after the United States designated Temporary Protected Status (TPS) for eligible Haitians living in the U.S., ${ }^{1}$ University of Miami law

* Clinical Instructor and Associate Director Health and Elder Law Clinic, University of Miami School of Law.

${ }^{+}$Associate Clinical Professor and Director, Health and Elder Law Clinic, University of Miami School of Law. We wish to thank the students, administrators, faculty, clinic staff and volunteers (too numerous to list by name) who made this project possible. We are also indebted to our research assistant, Robert Dale Noll, and to Davida Finger, Rachel Van Cleave, and Kele Stewart who read earlier vers ions of this piece and offered valuable comments. Our former colleague, Equal Justice Works Fellow Olga Porven, who has gone on to private practice, was an integral part of all of the work described herein, and Rebecca Sharpless, our colleague in the Immigration Clinic provided consultative expertise on numerous occasions.

${ }^{1}$ The Secretary of the Department of Homeland Security has the authority to designate TPS status for citizens from a foreign country where conditions temporarily prevent the safe return of that country's nationals, or where the country cannot safely or adequately receive returning nationals. On January 15 , 2010, Janet Napolitano announced designation by the Department of Homeland Security (DHS) of Temporary Protected Status ("TPS") for Haitian Nationals residing in the United States on or before January 12, 2010. TPS provided "a temporary refuge for Haitian nationals [then residing] in the United States and whose personal safety would be endangered by returning to Haiti." Press Release, Dep't of Homeland Sec., Office of the Press Sec'y, Statement from Homeland Sec'y Sec. Janet Napolitano on Temporary Protected Status (TPS) for Haitian Nat'ls (Jan. 15, 2010), http://www.dhs.gov/ynews/releases/pr_1263595952516.shtm. See Dep't Homeland Sec. Temporary Protected Status for Nationals of Designated States, 8 C.F.R. $\S \S 244.1-.20$; 8 U.S.C. $\S 1103$ (2010). Haitians who obtain TPS 
students, faculty and other volunteers became legal "first responders," assisting those in need. ${ }^{2}$ Our theory was that law students and lawyers have a unique set of skills that could be used to relieve suffering in Haiti and to assist Haiti's recovery effort.

In our view, an appropriate legal first response to the Haitian earthquake crisis that provided critical assistance during the first days and weeks after the earthquake had to be mounted from outside the country's borders. Commercial air traffic to the country was closed, ${ }^{3}$ and basic supplies were severely limited. Therefore, when

status cannot be removed from the United States or detained by DHS, can obtain authorization for employment, and can apply for authorization to travel. Requirements for TPS eligibility include continuous residence in the United States on and after January 12, 2010, no felony convictions, and no more than one misdemeanor conviction. TPS designation for Haiti is presently set to expire July 22, 2011. Temporary Protected Status, USCIS.GOV, http://www.uscis. gov/ por $\mathrm{tal} /$ site/uscis/menuitem.ebld4c2a3e5b9ac89243c6a7543f6dla/?vgnextoid=848f7f 2 ef0745210VgnVCM100000082ca60aRCRD\&vgnextchannel $=848 \mathrm{f} 7 \mathrm{f} 2 \mathrm{ef} 0745210 \mathrm{~g}$ nVCM100000082ca60aRCRD (last updated Oct. 7, 2010). At the time of the designation, DHS estimated that TPS would provide relief for 100,000 to 200,000 Haitian immigrants currently in the United States. American Immigration Council, Granting Refuge: Temporary Protected Status (TPS) for Haitians in the United States, Immigration Policy Center (Jan. 22, 2010), http://www.immigration policy.org/sites/default/files/docs/Granting_Refuge_012 210.pdf.

2 'While some definitions limit the term 'first responder' to emergency response personnel [such as law enforcement, firefighters and paramedics], disaster planners, and others recognize that attorneys sometimes serve as first responders. It is the lawyer's unique function in providing necessary legal services, or the relationship between the attorney's service and the client's relief from hardship and personal strife that accords this weighty title." Captain Evan R. Seamone, Attorneys as First-Responders: Recognizing the Destructive Nature of Posttraumatic Stress Disorder on the Combat Veteran's Legal Decision-Making Process, 202 MILITARY L. REV. 144, 144-45 (2009) (citations omitted); see also Scott Wylie, "After September 11: Disaster Preparedness: Document Protection: Guidance for Lawyers and Their Clients, 44 ORANGE COUNTY LAWYER 42, 44 (2002) ("Lawyers are often among the first responders after any major disaster in the United States-a fact unknown to many in our country."); Nancy Cook, Hurricane Katrina: The Storm Still Rages, 56 R.I.B.J. 43, 43 (2008) (observing attorneys' status as first responders in the provision of various legal services to victims of Hurricane Katrina).

${ }^{3}$ Commercial air traffic into and out of Haiti was closed for over a month 
TPS became available to Haitian nationals in the United States it created a perfect legal service opportunity to help Haiti from abroad.

As Miamians, we all recognized that the tragic events of January 12 had affected not only those Haitians in Port-au-Prince, but the entire Haitian country and diaspora. Haitians who were here in the United States were emotionally affected by the tragedy, and anxious to help financially, but many lacked work authorization. In a country where remittances were already equal to $30 \%$ of the preearthquake gross domestic product, ${ }^{4}$ a program that would deliver employment authorization documents to previously undocumented Haitians held tremendous promise as a means of infusing cash where it was most needed - directly to family and loved ones back in Haiti. ${ }^{5}$ Our law school Clinic, ${ }^{6}$ which does a significant amount of immigration status adjustment work, also had experience and expertise in applying for fee waivers from United States Citizenship and Immigration Services (USCIS), the agency that administers the TPS program. Without a fee waiver, the total cost of a TPS application was $\$ 470,{ }^{7}$ an amount many eligible Haitians in Miami

after the earthquake. Pascal Fletcher, American Flight Reopens Haiti Commercial Air Links, REUTERS (Feb. 19, 2010), 12:09 p.m., http://www.reuters.com/article/id USTRE61I46E20100219.

${ }^{4}$ Elliot Abrams, What Haiti Needs: A Haitian Diaspora, WASH. POST (Jan. 22, 2010), http://www.washingtonpost.com/wp-dyn/content/article/2010/01/21/AR 2010012103508.html.

${ }^{5}$ Our client files later proved this assumption correct as we collected evidence of remittances to Haiti as part of an individual's case. According to The World Bank, remittances to Haiti are expected to increase $20 \%$ in 2010 , meaning an up to $\$ 360$ million increase over normal levels. "Much of the increase this year will likely come from 200,000 undocumented workers granted 'temporary protective status' to live and work legally in the United States for 18 months." Haiti Remittances Key to Earthquake Recovery, THE WORLD BANK (May 17, 2010), http://web.worldbank.org/WBSITE/EXTERNAL/NEWS/0, contentMDK: 22582923 pagePK:64257043 piPK:437376 theSitePK:4607,00.html.

${ }^{6}$ See infra Sec. II.

${ }^{7}$ Temporary Protected Status - Haiti Questions and Answers, U.S. CITIZENSHIP AND IMMIGR. SERVICES, http://www.uscis.gov/portal/site/uscis/menuitem.5af9 bb959 $19 \mathrm{f} 35 \mathrm{e} 66 \mathrm{f} 614176543 \mathrm{f} 6 \mathrm{~d} \mathrm{l}$ a/?vgnextoid=b7755a40a $79 \mathrm{~b} 6210 \mathrm{VgnVCM} 10000$ $0082 \mathrm{ca} 60 \mathrm{aRCRD} \&$ vgnextchannel $=68439 \mathrm{c} 7755 \mathrm{cb} 9010 \mathrm{VgnVCM} 10000045 \mathrm{f} 3 \mathrm{~d} 6 \mathrm{al}$ 
could not afford.

This is the story of how we put an immediate-need and longer-term TPS service effort together, the lessons we learned in doing so, and what we believe to be a sustainable clinical pedagogy, and law school service model built around disaster assistance and recovery. ${ }^{8}$ We begin by examining how lawyers and law students have traditionally made valuable contributions to disaster response by using their legal training. ${ }^{9}$ All too often, those efforts have been hampered by the post-disaster ad hoc nature in which they have been constructed, and by the limitations inherent in the relatively small number of lawyers available to offer significant amounts of time to the overwhelming number of disaster-affected individuals. Recognizing this, many volunteer agencies and legal services providers have sought to improve the response time, quality, and quantity of post-disaster legal assistance by preparing materials and training volunteer lawyers in advance. ${ }^{10}$ Our proposal incorporates

RCRD (last updated Jul. 13, 2010).

${ }^{8}$ In writing about this service delivery model and our TPS work, we do not mean to suggest that Temporary Protected Status is a panacea for disaster victims living in the U.S. We are mindful of the many criticisms of the structural inferiority of such an immigration status. See, e.g., Lenni B. Benson, Separate, Unequal, and Alien: Comments on the Limits of Brown, 49 N.Y. L. SCH. L. REV. 727 (2005); Alison Mountz, et al., Lives in Limbo: Temporary Protected Status and Immigrant Identities, 2 GLOBAL NETWORKS 335 (2002). Nonetheless, TPS offered at least some protection and employment authorization for a wide swath of Haitians who had no other possible avenue to obtain any other lawful status.

${ }^{9}$ In defining disaster for the purposes of this article we have included a broader array of crises than those defined by, for example, the Robert T. Stafford Disaster Relief and Emergency Assistance Act (Stafford Act), 42 U.S.C.A. $\S \S$ 5121-22. In the context of this article, we view a disaster as any crisis that denies a significant group of individuals' basic human needs such as food, shelter, and adequate medical care; or that systematically deprives such a group of other basic human rights. Nor do we believe that disaster response should be seen as limited to crises that occur within our nation's borders. As discussed in this article, we believe that we made a contribution to Haiti through domestic legal work on behalf of Haitians within our borders. However, lawyers and law students are increasingly responding to problems outside the U.S. as well. See Scott Cummings, The Internationalization of Public Interest Law, 57 DUKE L.J. 891, 895 (2008).

${ }^{10}$ California Handbook for Disaster Legal Services, Office of Legal Servi- 
and builds on these improvements by arguing that law students and law clinics are a veritable "army" of untapped potential legal resources that could be configured to provide quick legal responses to emergencies and disasters, targeted to enforce disaster victims' basic needs. We encourage the legal community that is already working on emergency and disaster preparedness, relief and recovery to include law school clinics and students in their present efforts; and we encourage law school clinical instructors, and pro bono programs to give serious consideration to incorporating legal first response into their pedagogical and service programs.

\section{Lawyers and Law Students as Legal First Responders - Lessons From Historical Context}

As early as 1911, New York University law students organized to save more than 100 victims of the Triangle Shirtwaist Factory fire in Manhattan by pulling the young workers off the roof of the building and later providing testimony. ${ }^{11}$ In 1963, law students from across the country organized to form the Law Students Civil Rights Research Council, the first multi-racial law student run organization in the United States. The students traveled south to work with civil rights lawyers addressing the human rights crisis in the American south. The goal of the Council was to offer law students an opportunity to use their legal and organizational skills to attack the gross inequalities engendered by the widespread denial of basic human rights to racial minorities. The organization served as a training program for the student interns while providing direct legal

ces Foundation of the State Bar, STATE BAR OF CALIFORNIA 17(Aug.1997), http://1 egalassistance.law.af.mil/content/legal_assistance/cp/handbook_-_aba_disaster_leg al_services_california.pdf (recommending using continuing education credits to recruit attorneys to participate in training efforts to improve the quality of post-disaster legal response); Karen A. Lash \& Reilly Morse, Hurricane Katrina Special Edition, Mitigating Disaster: Lessons from Mississippi, 77 Miss. L.J. 895, 899 (2008) (highlighting the importance of drafting training and other materials prior to a disaster, as well as planning how to provide materials in disaster situations).

${ }^{11}$ Nicole Pezold, Remember the Triangle: A Century Later, New York Refuses to Forget the Fire That Changed History, NYU ALUMnI MAG., http://www. nyu.edu/alumni.magazine/issue15/15_square_Triangle.html (last visited May 11, 2011). 
assistance to needy communities and organizations, with over four thousand law students during the years the program was active. ${ }^{12}$

American lawyers' more recent responses to crises have been significant and impressive. Following the tragic events of September 11, 2001, an unprecedented number of legal aid organizations, bar associations, volunteer lawyers, and law students provided direct legal services to those affected by the $9 / 11$ attacks, addressing basic legal needs such as public assistance and disaster benefit applications, immigration issues, and landlord-tenant matters. ${ }^{13}$ In an effort to enhance legal response efforts in future disasters, stakeholders in New York's legal community produced a set of findings and recommendations based on their experiences that have particular relevance to this discussion. The report emphasizes the importance of organization and training in disaster-related legal assistance $^{14}$ and recognizes that disaster victims are often unable to access life-sustaining and crucial services without help. "People... were in too much shock and grief to be able to work their way through the labyrinth of service organizations. [1] t was hard. You had to know who was offering what assistance, what their criteria were, and how one would impact another."15 The report also recognizes the crucial importance of funding for the effort, swift response time, and that law students can make a significant contribution if properly trained. ${ }^{16}$ As discussed below, we view the large-scale deployment of law students as a vital component of legal disaster response "in order to increase the breadth of resources available to aid victims." 17

${ }^{12}$ Law Students Civil Rights Research Council Records: 1961-1994, Princeton Univ. Libr.: Dep'T. OF Rare Books and SPECIAl Collections, MUDD , PUBLIC, http://arks.princeton.edu/ark:/88435/hd76s005t.

13 Judith S. Kaye, Public Service in a Time of Crisis, 31 FordHAM URB. L.J. 831 (2004).

\footnotetext{
${ }^{14}$ Id. at $843-67$.

${ }^{15} \mathrm{Id}$. at 881 .

${ }^{16} I d$. at $932-33$.

${ }^{17}$ Id. at 932.
} 
Following a series of hurricanes affecting Florida in 2004, the Florida Bar Foundation funded and produced the Florida Legal Assistance Disaster Manual. ${ }^{18}$ The Manual was developed to provide a roadmap to prepare the Florida legal services community to distribute their services to low-income families and communities in the wake of disaster. It also provides a step-by-step guide for what a legal services agency should do before and after a disaster to prepare, respond, and rebuild, taking into consideration the fact that the legal aid office itself may be impacted by the disaster. ${ }^{19}$ The Manual discusses how to develop and coordinate disaster legal resources, how to collaborate with other providers in the state, and how to incorporate annual disaster trainings into the regular training schedule of the agencies. ${ }^{20}$ It focuses on FEMA-related disaster assistance and contemplates coordination between legal services, community organizations, and pro bono legal assistance through volunteer attorneys, though it does not discuss the role of law students. The Manual was created in an effort to improve upon what had previously been ad hoc responses to disaster. ${ }^{21}$ As the drafters acknowledged, "the 2004 hurricane season, which engendered four severe disasters within a one-month span and impacted legal aid programs throughout Florida, taught us that we need to have a concerted plan., 22

Some of the challenges that Florida legal aid offices reported and learned from following the 2004 hurricane season were very much present in the Gulf of Mexico region only a year later after Hurricane Katrina's 2005 landfall. $^{23}$ Many legal services providers,

${ }^{18}$ Florida's Legal Assistance Disaster Manual, FLA. BAR FOUND., (Jun. 2006), http://www.flabarfndn.org/resources/disaster-manual/manual-files/2006_Di saster_Manual.pdf.

${ }^{19} \mathrm{Id}$

${ }^{20} I d$. at Secs. IV-V (A)-(B).

${ }^{21}$ Id. at Sec. I.

${ }^{22}$ Id.

${ }^{23}$ Michael H. Rubin \& Beth E. Abramson, Lessons Learned (the Hard Way) by Lawyers During Hurricanes Katrina and Rita, ABA PROB. \& PROP. Sept. - Oct. 
as well as the local potential volunteer attorney base, were effectively shut down by the storm. "The offices and practices of many lawyers in Louisiana and Mississippi were demolished by the storms. Offices were flooded and records destroyed. Clients were scattered, many never to return. Courts were closed for months." 24 A number of forward-thinking organizations and individuals began to marshal the untapped capacity of law students to assist in responding to the enormous legal needs created by this disaster.

Equal Justice Works, a non-profit organization located in Washington, D.C., identified the important legal needs in the Gulf Coast region and implemented an innovative legal disaster relief program to assist a number of the communities affected by Hurricanes Katrina and Rita. ${ }^{25}$ Focusing on five substantive legal areas (housing, insurance, consumer, disaster relief programs, and family law), the organization created the Summer Corps program, which placed lawyers in longer-term fellowships and first- and second-year law students in 300 hour summer internships designed to provide direct legal services and policy advocacy in the five areas of identified legal need. Gulf Coast region legal aid organizations provided host sites for these components. ${ }^{26}$

At the same time, the law students and clinics at Loyola and Tulane tapped into the law student community to serve victims of the hurricane. After Hurricane Katrina, Loyola Law School relocated to Houston, and students and faculty created the Katrina Advice Clinic. Volunteer law students staffed the Clinic, responding to requests for information from hurricane victims on issues such as insurance, FEMA, and child custody. ${ }^{27}$ After its first year, the Clinic students

2006.

${ }^{24}$ Rubin \& Abramson, supra note 23.

${ }^{25}$ Sara Debus \& Seri Irazola, Delivering Legal Aid after Katrina: The Equal Justice Works Katrina Legal Initiative, URBAN INSTITUTE i, 9-10 (Aug. 2009), http://www.urban.org/uploadedpdf/411946_legal_aid_katrina.pdf.

${ }^{26} I d$.

${ }^{27}$ Pro Bono Placement Opportunities, LOYOLA UNIV. NEw ORLEANS, http:// www.loyno.edu/gillislong/pro-bono-placement-opportunities (May 11, 2011). 
directly represented low-income people, ultimately representing thousands on FEMA, Road Home, and land use (demolition) issues. ${ }^{28}$ A key part of this effort involved working closely with local grassroots groups who played an important role in identifying needs and distributing legal services. ${ }^{29}$

Tulane law student Morgan Williams worked with others at Equal Justice Works to found the Student Hurricane Network, which engaged hundreds of law students from more than 60 law schools. ${ }^{30}$ The students contributed countless hours of legal research and provided direct legal assistance to hurricane victims. ${ }^{31}$ The lawyers with whom these students worked provided testament to their capacity:

"The students have performed in every phase of the civil and criminal system," says Loyola University New Orleans law professor Bill Quigley, who is also the director of its law clinic and poverty law center. He has deployed hurricane network volunteers to help flood victims facing evictions, foreclosures, rent gouging, and other housing issues. Other law students have traveled to prisons across Louisiana to track where inmates had been shipped and to investigate their conditions in preparation for civil lawsuits. "[The students] were extraordinarily useful," says Pamela Metzger, director of Tulane's criminal law clinic. "I think for those who went to law school wondering if there was still a chance to be law heroes, the answer is in the affirmative." 32

Law students have also provided valuable assistance to immigrant and language minority communities who are often

${ }^{28}$ E-mail from Davida Finger, Assistant Clinical Director, Loyola University New Orleans, to JoNel Newman, Associate Clinical Professor and Director, Health and Elder Law Clinic, University of Miami School of Law (Dec. 20, 2010, 10:15:02 EST) (on file with authors).

${ }^{29} \mathrm{Id}$.

${ }^{30}$ Ann Farmer, The Gulf Coast Needs You, Student Law. Sept. 2006, http://www. abanet.org/lsd/studentlawyer/sept06/gulfcoast.shtml.

${ }^{31}$ Id.

${ }^{32}$ Id. 
disproportionately impacted by disaster. The national and local Asian community quickly identified legal services as a large unmet need for Asians in the post-Katrina Gulf, particularly for those with limited English proficiency, and particularly in the area of immigration assistance. ${ }^{33}$ Working with Houston Volunteer Lawyers and New Orleans Legal Assistance, and incorporating assistance from law students, the community mobilized to try to fill these needs. ${ }^{34}$

When the legal first responders discussed above reflect upon the lessons learned from their forays into disaster response, several themes emerge that are relevant here. One of the most significant themes is that many of these legal first responders believed that their mission suffered from not being fully integrated into other, more traditional, disaster response thinking, organization and planning. The New York report states:

[I]t would have been helpful to partner fully with the United Way and the Red Cross, which together with Safe Horizon spearheaded the overall New York City response to the tragedy. Through greater cooperation, service delivery could have been streamlined, thereby reducing duplication and improving the quality and range of services available to people affected by the tragedy. To maximize their effectiveness, lawyers must be seen as an integral part of a community's emergency response team and to this end should continually work to build relationships with such social service and disaster response agencies. ${ }^{35}$

This sentiment is echoed in several other post-disaster

${ }^{33}$ Tuyet G. Duong and Juliet K. Choi, Hurricane Katrina: Models for Effective Emergency Response in the Asian American Community, ASIAN AMERICAN JUS- TICE CENTER, http://www.advancingequality.org/attachments/files/ 34/KatrinawriteupFINAL.pdf (last visited May 11, 2010).

${ }^{34}$ Duong \& Choi, supra note 33.

${ }^{35}$ Kaye, supra note 13 , at 938. 
reports. ${ }^{36}$ Additional themes in these reports include the need for predisaster organization and planning, ${ }^{37}$ as well as the need for rapid response after a disaster. ${ }^{38}$ Many of the analyses explicitly recognize how disaster impacts most harshly on the most vulnerable, including immigrants. ${ }^{39}$ As lawyers are better understanding their vital role as legal first responders in the wake of disaster incorporating the lessons learned by those who have done this work becomes increasingly important for future planning.

\section{Our Experience with Law Students as Legal First Responders}

On January 19, 2010, University of Miami law students became legal first responders working through and with our Clinic. The Health and Elder Law Clinic is an in-house clinic at the University of Miami School of Law in which law students assist lowincome elderly and health-impaired clients under the supervision of a professor and licensed attorneys who provide clinical instruction. ${ }^{40}$

${ }^{36}$ See, e.g., Russell Engler, Public Service as the Crisis Fades, 31 FORDHAM URB. L.J. 983, 1006 (2004) (explaining that collaboration with social services is necessary as part of a program for the community to maintain confidence in the court); Maria R. Volpe, Ph.D., Symposium - ADR in the Aftermath Post-Disaster Strategy: Taking Stock: ADR Responses in Post-Disaster Situations, 9 CARDOZO J. CONFLICT RESOL. 381, 394 (2008) (stating that alternative dispute resolution practitioners need to build relationships with community leaders so they will be called upon when a disaster arises); Lash \& Morse, supra note 10, at 899 (recommending the legal community to build relationships with social service agencies and government agencies to facilitate coordination and trust).

${ }^{37}$ See, e.g., Kaye, supra note 13, at 929; Volpe, supra note 36, at 394.

${ }^{38}$ See FLA. BAR FOUND., supra note 18, §VII, at 14; Kaye, supra note 13, at 933; Duong, supra note 33, at 13.

${ }^{39}$ See generally Duong \& Choi, supra note 33 (stating that immigrant communities, particularly Southeast Asian, often working in cash economies, suffered from delayed relief following Hurricane Katrina); Kaye, supra note 13 (explaining that a bar association created an Immigration Help Desk after recognizing a large undocumented worker population in the businesses around the World Trade Center lost their jobs following 9/11 who were afraid to request assistance from other traditional channels).

${ }^{40}$ See http://www.law.miami.edu/clinics/helc.php (last visited May 17, 
The Clinic is population-based and operates in cooperation with health care providers at the University of Miami Miller School of Medicine's teaching hospital, who refer the majority of our clients, many of whom are of Haitian background. ${ }^{41}$ We use a "teaching hospital" approach as well, providing student lawyers with a dynamic, high-intensity and high-volume practice. ${ }^{42}$ Clinic students function as the client's primary advocate in all aspects of the client's cases. The Clinic's general philosophy about client representation is "holistic" - our goal is to meet all of our clients' legal needs on the theory that they will not get these legal services elsewhere. ${ }^{43}$ Because we provide legal services to extremely poor, healthimpaired, and vulnerable groups in Miami, our practice principally involves representation of clients in public benefit and entitlement programs, disability, advance directives, and immigration. Each year we select a small group of former Clinic students as student fellows whose role includes representing clients in more advanced and complicated cases, taking on policy and impact advocacy projects, as well as serving as peer supervisors to students in their first clinical year. Following the January earthquake in Haiti, we realized our Clinic's experience and focus on public benefits and immigration issues might allow us to assist relief efforts, but we did not fully appreciate the formidable scope of the task we undertook.

\section{A. "Fools Rush In. . ,"44}

As mentioned above, our Clinic students were anxious to assist in Haiti relief efforts, and we, as their clinical instructors,

2011).

${ }^{41} \mathrm{Id}$.

${ }^{42}$ See JoNel Newman, Rethinking Clinical Pedagogy (Jan. 12, 2011) (unpublished manuscript) (on file with author).

${ }^{43}$ JoNel Newman, Re-Conceptualizing Poverty Law Clinical Curriculum and Legal Services Practice: The Need for Generalists, 34 FordHAM URB. L. J. 1303 (2007).

44 "... where angels fear to tread." ALEXANDER POPE, AN ESSAY ON CRITICISM 36 (1711). 
wanted to provide them an opportunity to use their legal skills to do so. Without pausing to seriously consider whether the Clinic was prepared to embark on this new endeavor, we enlisted the law students as legal troops - first responders who had an immediate impact on the Haiti recovery and relief efforts. However, despite the fact that the Clinic is located in South Florida, which has a history of natural disasters, we were ill-equipped to respond to any emergency - we had no plan, manual, or emergency preparedness training. We had not thought about or discussed what our potential legal response would be - if any at all - to the community, in the event of a disaster. However, in this instance, once the TPS designation for Haiti appeared inevitable, we immediately recognized what we could to do to assist - we just had no idea how to do it, or what we were getting ourselves into.

We never expected to represent clients in TPS cases. We had previously referred out far simpler TPS renewal cases for persons from Honduras and El Salvador because it was outside the scope of our expertise and there were other non-profit organizations who would take the cases. Our Haitian TPS project was a spur-of-the-moment experiment, utilizing law students as a veritable army of legal first responders to a disaster abroad by representing clients locally.

On reflection, there were three stages to what we did as advocates in disaster response - stages that track the experiences of other responders. ${ }^{45}$ Initially, we held a mass TPS event for rapid response. This was followed by a longer-term "campaign" that required intense community outreach and a constantly revolving set of volunteer law students on spring break from institutions around the country, producing a large number of quality TPS applications in a short period of time. By late March, we had a significant amount of experience dealing with the vagaries of getting these applications through the government bureaucracy; enough so that we recognized patterns of problems in their adjudication. Thus, the third stage of our disaster relief efforts consisted of policy advocacy, as well as

${ }^{45}$ See FLA. BAR FOUND., supra note 18; Lash \& Morse, supra note 10. 
mopping up loose ends on individual cases. Each of these stages, the steps taken, and the lessons learned are discussed below.

\section{B. TPS Mass Intake Drive}

\section{Mounting the Campaign}

On January 19, 2010, we called an emergency "firm" meeting to offer our students the opportunity to respond to the disaster in Haiti as legal troops conducting a mass TPS drive on the medical school campus on Friday, January 22, 2010 - just one week after the Haitian TPS designation. ${ }^{46}$ The drive would consist of mass client intakes, initial eligibility determinations, document preparation, collecting evidence, and then filing and representing Haitians in TPS cases. Next, we recruited Alison Flowers, a third year Clinical Fellow, as the TPS project leader. She immediately contacted our partners at the medical school and community hospital to explain our plan and ask them to promote the drive. They generously agreed to provide us with an office suite, distribute flyers advertising the event, and refer patients who would potentially benefit from TPS. We announced our plan to conduct a mass TPS drive and invited the entire law student body. Over sixty law students participated in this immediate surge. On Wednesday, January 20, 2010, volunteer immigration attorneys conducted a TPS "boot camp" to train Miami law students on substantive TPS law, the application and interview process and the common stumbling blocks to establishing eligibility. ${ }^{47}$ We conducted our own parallel training on client interviewing and counseling, ethics and confidentiality.

${ }^{46}$ See Press Release, Dep't of Homeland Sec., supra note 1.

47 The attorneys - to whom we remain indebted - are Linda Osberg-Braun, Melissa McNameeVenceslau and Jose Latour. Portions of their training presentation, which was widely shared after the earthquake and TPS designation, can be accessed online. Obtaining TPS for your Haitian Clients, ABA, http://www.americanbar.org/content/dam/aba/migrated/disaster/docs/obtaining_tip s.authcheckdam.ppt\#257,1, OBTAINING TPS FOR YOUR HAITIAN CLIENTS (last visited May 11, 2011). 


\section{Routinized TPS Intake}

The organization, planning, and creation of a routinized system were key components of the project. Extensive thought went into engineering a plan to execute the TPS intake drive, preparing the applications, and filing them with USCIS. Our objective was to devise the blueprints for a systematized mass intake and application process that inexperienced law students could follow with facility to deliver effective and competent legal services to TPS applicants. In order for this to take place, we identified the potential issues that could arise and designed a virtually foolproof plan of attack that minimized the risk of error, including a TPS intake toolkit, an intake day operational plan, a signature TPS application packet, and a routinized system for submitting application packages to USCIS.

\section{a. TPS Intake Toolkit}

Part of our strategy was to equip students with a customdesigned TPS intake toolkit that included intake and application forms, secured in order of operation in a file folder with prongs. The TPS toolkit functioned as a roadmap that students could use as their intake guide. All forms were translated into French and Haitian Creole. The first form was a contact questionnaire that functioned as an icebreaker and proved essential to follow up with clients postintake. The second form was a limited retainer stating that the Clinic was only representing the client in a TPS application. The third form was a notice of appearance on behalf of the individual applicant. After that came our in-house fee waiver form and affidavit, which we adapted to comport with the TPS criteria. Students used this form to determine whether the client was eligible for a fee waiver based on income and expenses. ${ }^{48}$ Next were the USCIS TPS and Employment Authorization Document applications. These forms are filled with difficult, confusing, and ambiguous questions, and one wrong,

48 Our experiences with the agency's administration of the fee waiver process resulted in a series of negotiations and policy advocacy later in the process in which our clinic students participated. See infra Sec. II.C. 
incomplete, or misunderstood answer can lead to a denial. ${ }^{49}$ The last document was a client "homework" form that included our contact information and a list of information and/or documents we needed from the client in order to complete their application. The students were tasked with understanding for themselves and then explaining each form to the clients, and securing the needed signatures. Students prepared a fee waiver for each applicant who was unable to pay the $\$ 470$ fee. $^{50}$

\section{b. TPS Operational Plan}

An operational plan was essential. First, we decided how to use the space. The intake site was an office suite at the medical campus that contained three main rooms. The classroom was designated as the main TPS intake room, a smaller conference room doubled as a break, supply, and sign-in room, and a medical exam room housed the attorney review team. ${ }^{51}$ The law students met in the conference room for breakfast, orientation, and a debriefing. Next, our project leader assigned student roles. Some students greeted potential clients, gave out waitlist numbers, and directed traffic. Others conducted intake in teams of two, using the TPS toolkit.

${ }^{49}$ For example, the TPS Application asks at section $2 \mathrm{~h}$ if you have ever "been excluded and deported from the United States within the past year, or have you been deported or removed from the United States at government expense within the last five years." USCIS Form I-812, Application for Temporary Protected Status, OMB No. 1615-0043 (Rev. 11/23/10), http://www.uscis.gov/i812 (last visited May 11, 2011). Many individuals eligible for TPS may have deportation orders from the U.S. government and this question oddly enough is not designed to elicit a "yes" response from individuals who are simply ordered deported or removed. The question is actually seeking information about those individuals who have been physically removed following a deportation order.

${ }^{50}$ USCIS Form I-912 Request for Fee Waiver, OMB No. 1615-0116 (Expires 10/31/2012), http://www.uscis.gov/i-912 (last visited May 11, 2011).

${ }^{51}$ We made a list of office supplies beforehand and brought everything with us. As Napoleon Bonaparte famously observed, "an army travels on its stomach." Al Bihani v. Obama, 594 F. Supp. 2d 35, 40 (D.D.C. 2009). We knew we would have to keep the students fed and hydrated. We also did not want them to leave. So we arranged for coffee, water, breakfast, lunch, and snacks. 
Since our Clinical students already had extensive practice in interviewing potential clients and conducting intake interviews we paired them with other law student volunteers. If students encountered a problem, issue or question they were instructed to raise their hand and the more experienced Clinical Fellows would assist them, confirming with the on-site lawyers. Student "runners" made photocopies ${ }^{52}$ of documents and, if necessary, drove clients to get passport photos, money orders, or documents from home. ${ }^{53}$

When students finished an intake, the Clinical Fellows reviewed the packets and brought each file to the attorney room for lawyer review. Lawyers reviewed the intake files to ensure that the student had collected sufficient information for processing the application and to enable us to contact the client later, then met with all the clients and painstakingly reviewed every document before the students advised the clients they could leave. Once the attorney was satisfied that the file was as complete as possible, she would file the intake folder in a banker's box, and, if necessary, the student would then give the client the "homework" form. At the end of the day, we packed up and returned over sixty application folders to the Clinic where they were filed and organized until we were ready to process the applications to send to USCIS.

\section{The Application Filing Process}

A week after the mass intake drive, law students arrived at the Clinic office to finalize and submit the TPS applications. In order to routinize the filing process, we set up a system to file all the TPS applications with USCIS on one day using our signature TPS application packet. We developed an assembly-line filing process that a law student could easily follow and that USCIS could accurately process.

52 Because copying documents at remote locations proved to be a difficult challenge, we eventually invested in two portable copiers with the support of Miami Law's public interest resource center, HOPE.

${ }^{53}$ Our fear was that if we sent them away to get something they might never make it back. 


\section{a. The Signature Application Packet}

We developed an easily identifiable, uniform Clinic TPS application packet designed to streamline the process with USCIS. Each application packet looked the same with a bright red cover that stated "HAITIAN TPS PLEASE EXPEDITE." We attached passport photos (and money orders, if applicable) to the red cover in transparent bags. Next was a cover letter on Clinic letterhead stating that we were representing the client. and a list of the documents and applications enclosed. The next document was our notice of appearance. $^{54}$ If the client was unable to pay the fee, we attached our uniform fee waiver form and accompanying evidence. Last were the USCIS TPS and Employment Authorization Document applications, each with separate supporting evidence. Each piece of evidence was preceded by a yellow coversheet with the title of the document and the reason for submission. This initial investment of time ultimately expedited the process because any student could follow the template to prepare a TPS application. It was also easier for the supervising attorneys to review these standardized applications. Most importantly, the packet was an advocacy piece that gave clients the best chance of being approved for TPS quickly because it was easy for USCIS to follow and adjudicate.

\section{b. Quality Control}

After we oriented students to the process and template, each student got two TPS files to prepare and finalize for submission to USCIS. Students prepared files, then went through a peer and

${ }^{54}$ We individually appeared in every application that we filed because it was our belief that most of our clients would not be able to follow through with the application and potential Requests for Evidence on their own. We suspected that the application was the first step in a complicated immigration process that the client could not navigate without an advocate. We felt attorney follow through was imperative to the success of the applications. We believe that our experience supports our initial assumptions. One hundred percent of our fee waivers were approved, and ninety-seven percent of our TPS applications have been approved to date. Internal University of Miami Health \& Elder Law Clinic spreadsheet, Haitian TPS Cases - Status (Jan. 14, 2010) (on file with authors). 
attorney review session, after which the applications were mailed as a group at the end of the day.

In order to begin the process, the students first ensured application accuracy and TPS eligibility. ${ }^{55}$ If categorical eligibility issues arose, attorneys would instruct students to follow up with the client and/or conduct further research and write a memo addressing the issues. If the applicant was TPS eligible, and we had all the required documentation and verification, then the student would prepare the packet for further review.

Working from an attorney review checklist we, along with volunteer immigration attorneys, reviewed each client file and packet to ensure accuracy and eligibility. Many packets were sent back to the students for corrections, precision, and completeness. Students learned from their initial mistakes and were much more accurate and efficient as the day progressed. Once an attorney deemed the case ready to file, the student would make a copy of the entire application for our case file, as well as generate a client case status letter in English, Haitian Creole and French for each client, based on a uniform Clinic template we developed. ${ }^{56}$ As applications were completed throughout the day, we organized our documents for filing. We had one stack of TPS applications, one stack of our client files, and one stack of client status letters. The Clinic had an assembly line process for the final stage, including a mailing system with one student as the "FedEx" gatekeeper. As a team, we verified that each application packet was in a trackable FedEx envelope, that a copy of the application was in our client file, and that the corresponding client letter was in a sealed envelope ready to be mailed. We then simultaneously submitted the applications to

${ }^{55}$ This was a challenge. The applications required extensive information about immigration and criminal history. Both are difficult to recreate because the records are difficult to find, clients do not remember everywhere they have previously lived, do not understand the complex legal terms applied to their situations, and online databases are often inaccurate.

${ }^{56}$ The client status letter informed the client that we filed their TPS application, and they should contact us immediately if they received any USCIS correspondence. 
FedEx, sent all the client status letters, and filed the copies in the Clinic office. We were the McDonalds of TPS. ${ }^{57}$

\section{Transition from Intake Model to Outreach Model}

By the end of January, numerous law students, clinical programs, and pro bono service groups began to contact us to ask if our Clinic could host them during their spring break to continue our TPS project. Ultimately, we agreed to host seven law schools ${ }^{58}$ for the entire month of March because we mistakenly believed that the numbers we produced at the initial TPS mass intake were indicative of the numbers we would see in the months to come. USCIS and legal services providers had also predicted that hundreds of thousands of Haitians would come forward to apply for TPS. ${ }^{59}$ When we had agreed to host the law students over spring break we thought we would just deploy them to the community hospital where we had done our first intake and potential applicants would continue to show up in large numbers. We quickly realized that if our goal was to continue assisting people - particularly the most vulnerable apply for TPS our service delivery model would need to change. There were no longer lines of people beating down the door asking for help with TPS, though we knew that need in the community still existed.

${ }^{57}$ Dick and Mac McDonald transformed their already profitable drive-in business in the 1940's by reducing the number of items on their menu, ditching the drive-in in favor of a self-service counter, and re-configuring their kitchens to support an assembly-line process. This allowed the restaurant to focus on mass production, speed, and volume, which eventually led to the franchise empire of today. McDonald's History, MCDONALD's CANADA, 1, http://www.mcdonalds.ca/ pdfs/history_final.pdf (last visited May 11, 2011). Our goal was creating a similar assembly-line process that would enable us to quickly and efficiently service our clients, utilizing students who lacked the knowledge and experience to understand the entire process but had a strong desire to help with such an important goal.

${ }^{58}$ See supra Sec. II.B.for participating law schools.

59 Alfonso Chardy, Feds: Up to 200,000 Haitians Expected to Apply for TPS, MIAMI HERALD, Jan. 20, 2010, available at http://mo.palmbeachpost.com/ news/feds-up-to-200-000-haitians-expected-to-1878 43.html. 
For the entire month of February, we transitioned from our mass TPS intake drive model, which waited for applicants to show up, to a "Get Out the Vote" style campaign, ${ }^{60}$ going door to door educating the community about TPS and offering assistance with TPS applications. We designed a standardized outreach and education program in which clinicians and students hit the streets of Miami every weekend as community educators and organizers to spread the word that TPS was still available, and that we offered pro bono assistance with TPS and fee waiver applications to those unable to pay the fees. We determined where the community most in need was located, distributed flyers and information, spoke to shopowners, and went to churches, supermarkets, restaurants, and hair salons. We "canvassed" the affected community neighborhood by neighborhood, block by block, and house by house, providing door to door mini-TPS presentations. ${ }^{61}$ We always wore Miami Law Tshirts and people began to recognize us as "the people doing TPS" and welcome us into the community. We also joined forces with a local restaurant, Chef Nicole, in the heart of Little Haiti, to essentially create a TPS community outpost; a store-front legal services operation to which we could send the new troops to conduct TPS intake. We invited people to call the Clinic if they had questions, or needed more information.

The transition to outreach laid the groundwork for the alternative spring break students to continue to educate the community and assist clients because, as the students arrived, the community correctly assumed they were part of the Miami Law group that had been in their community educating about TPS, since

${ }^{60}$ This is a popular term for increasing voter participation through outreach programs. See generally Donald P. GREEN \& AlAN S. GERBER, GeT OUT THE VOTE: HOW TO INCREASE VOTER TURNOUT (The Brookings Institution, 2d ed. 2008) (describing the effectiveness of various voter mobilization techniques).

${ }^{61}$ Robert C. Jones, Jr., Obama's Bill: School of Law Helps Haitian Immigrants in Miami Apply for Temporary Protected Status, THE UNIV. OF MiAMI MAG., Summer 2010, http://www6.miami.edu/miami-magazine/summer 2010/ featurestory2.html ("If we saw people barbecuing in their yards, we'd stop and talk to them,' says Melissa Swain, a supervising attorney with the clinic."). 
February. This outreach was essential to the success of the Alternative Spring Break TPS Project.

\section{Alternative Spring Break TPS Project}

We began our Alternative Spring Break TPS Project on March 1, 2010. We hosted students from across the country who enlisted as an impromptu legal corps to help Haitians in Miami apply for TPS. Our system required adaptation in order to telescope the complete TPS intake, preparation, and final filing process into a single week. We were committed to each spring break student having represented at least one Haitian TPS seeker from initial interview to final submission of TPS application to USCIS. We were also committed to teaching these volunteers about the community, the lawyering process, and the applicable law. The week-long process we developed was based on clinical pedagogy and therefore the program doubled as a clinical immersion program. Not all of the participating law students had had the chance to participate in a clinic at their home law school. We provided them the opportunity to learn and practice in a clinical setting.

Our theory was - since we already had a systematized TPS procedure - we could "plug in" new students and simultaneously expand our service delivery model to help more individuals file for TPS. We streamlined the process over four separate weeks with seven different law schools. By standardizing the process, any law student introduced to the system could produce consistent outcomes, and file a TPS application. We used the knowledge, practice and experience we had gained in January and February to develop a week-long program. The Health and Elder Law Clinic hosted over seventy law students from law schools across the nation including New England, Santa Clara University, Stanford University, University of California Berkeley Boalt Hall, University of Memphis, University of Miami, and University of San Francisco. 


\section{The Spring Break Operational Plan}

Student groups arrived at the law school on Monday mornings. Health and Elder Law Clinic student liaisons were in charge of welcoming, introducing the operational plan, and conducting an icebreaker session. The Clinic students used a PowerPoint presentation to train the incoming students on substantive TPS law, ethics, and client interviewing. The TPS intake toolkit and signature TPS application packets were distributed and the spring break students reviewed completed intakes and applications that had previously been filed and approved by USCIS so they could envision the finished product. From the first day, we made it very clear that by Friday, each student was expected to file an application for each eligible person they interviewed.

Our Clinical Fellows then conducted a mock TPS intake. Students were trained to do empathetic client interviews that marshaled the necessary facts to apply for TPS. Then the visiting students were divided into pairs to do their own mock intakes. They went through every document in the packet and practiced explaining forms, asking difficult questions, and obtaining necessary client signatures.

Students dedicated Monday afternoons to community education and outreach, both to introduce the students to the community, and because it was the best way to ensure that persons needing our assistance found it. We told the visiting students that this project was similar to a "Get Out the Vote" campaign and that part of their role was as community educators and organizers - to explain what TPS was, what the benefits and potential risks were, and who was eligible for the program. ${ }^{62}$ It was clear from our prior outreach that the community was full of potential TPS eligible Haitians who could benefit from assistance, but that many did not know what TPS was, how much it cost, or whether they could apply. There was confusion and misinformation in the community regarding eligibility, cost, and the availability of fee waivers. Before the

${ }^{62}$ See GreEN \& Gerber, supra note 60. 
students were deployed, they practiced introducing themselves and providing information. Alternative Spring Break students educated the community about TPS in general, provided information about fee waivers, fielded questions, and distributed flyers. They went to the Miami's Little Haiti neighborhood dressed in Miami Law t-shirts and accompanied by our Clinic student liaisons who were already familiar with the neighborhood. This exercise was aimed at helping students understand the day to day realities of the client community, learn to communicate effectively outside their comfort zone, and to expose them to race and cultural diversity issues while providing much needed services.

Tuesdays were the major TPS intake day. Students were posted at the community hospital and our Little Haiti outpost, Chef Nicole Restaurant. Outreach and education also continued for much of the day. People were constantly asking who the students were, what the students were doing, and questions about TPS in general. The students' presence in the community served to raise visibility both about TPS and about the availability of free legal help. Students worked in pairs interviewing clients. Because the intake packets were standardized and laid out in logical order, students were able to get through them without having to remember what to do next. The intake packets could not predict or help with every single potential issue and so the students also got experience in how to be on-the-spot problem solvers. There were times when the applicants had no documents with them and students would have to piece together their story. We had attorneys and Clinical Fellows posted at both sites to field and resolve any questions or issues that arose. At the end of the day, the files were collected from each site and brought back to the clinic.

Wednesdays were devoted to standardized clinical case rounds and a firm meeting. Students and attorneys worked together to analyze each case according to a five-step process:

(1) Fact and Issue Presentation;

(2) Fact Questions and Clarification;

(3) Issue Designation; 
(4) Alternative Solutions and Recommendations; and

(5) Plan of Attack. ${ }^{63}$

For step one, the visiting students would present the facts of the particular TPS intake they conducted, and any eligibility issues they perceived. This methodology was similar to briefing a case and the students were able to grasp the concept pretty easily. However, most of the time students did not initially present all the facts necessary for the attorneys to determine whether the person was TPS and/or fee waiver eligible. In these cases, the attorneys and other students would move to step two and follow up with questions regarding the missing factual information. In other instances, the facts were not presented accurately and the follow-up questions would focus more on clarification. The student representing that client would respond to the questions with more facts, clarify others, or determine what information they needed to obtain and follow up with the particular client.

In cases in which the facts were complete, the group would move on to step three to analyze the case, determine TPS and fee waiver eligibility, and identify any remaining issues. Depending on what issues remained in the case, the group would begin step four and suggest alternative solutions to resolve those remaining issues. Some cases were straightforward, requiring that the student gather additional evidence or follow up for more information while others were more complicated with categorical eligibility problems requiring research. For example, there were many cases in which establishing Haitian nationality required research and factual investigation since USCIS initially took the position that a Haitian birth certificate alone was insufficient to establish Haitian nationality. After we discussed alternative solutions and follow-up actions were taken, we were able to move to step five and decide if

${ }^{63}$ See Susan Bryant \& Elliott S. Milstein, Rounds: A "Signature Pedagogy" for Clinical Education?, 14 CLINICAL L. REV. 195 (2007); Jayashri Srikantiah \& Jennifer Lee Koh, Teaching Individual Representation Alongside Institutional Advocacy: Pedagogical Implications of a Combined Advocacy Clinic, 16 CLINICAL L. REV 451 (2010). 
the claimant was eligible and what the next steps would be in order to file the case.

On Thursdays, students triaged their cases and began preparing the applications. Many had to return to the community to follow up with clients and collect necessary documents, while others remained on campus to conduct additional research. Our Health and Elder Law Clinic students and attorneys fielded questions as the day progressed and reviewed research memos. As new facts, issues, or problems surfaced, we used the case round model described above to re-evaluate the case and determine if a new plan of attack was necessary.

Friday was reserved primarily for the final processing, quality control, and submission of the TPS applications. The standard operating procedure followed our prior "filing day" experience. The students used the signature TPS application packets and the attorneys reviewed them prior to filing. By the end of March, Alternative Spring Break students had filed over 90 TPS applications.

\section{TPS Policy Advocacy Project}

By late March, various problems with USCIS's handling of the TPS process began to surface. We recognized the need for a concerted policy advocacy effort regarding TPS adjudication, as did a consortium of other pro bono and legal services organizations. ${ }^{64}$ We collaborated with local and national groups that provided direct representation to TPS applicants, as well as those whose work focused primarily on policy advocacy regarding systemic TPS processing and adjudication problems that arose after the designation

${ }^{64}$ These groups included Catholic Charities Immigration Legal Services of Washington, D.C. and New York, Catholic Charities Legal Services of Miami, and the Florida Immigrant Advocacy Center of Miami along with pro bono assistance from the firm of Hunton \& Williams. Letter from Douglas Heffner, James Rubin, and Suzan Kern of Hunton \& Williams to Alejandro Mayorkas, Director, U.S. Citizenship and Immigration Services (Apr. 26, 2010) (on file with authors) (the letter includes a list of five main advocacy agencies, including the Clinic, and 53 additional signatories). 
of TPS for Haiti. The systemic issues that TPS applicants and advocates complained of included erroneous and widespread fee waiver denials, requests for evidence, proof of Haitian nationality and/or continuous presence, residence in the U.S., lack of clarity regarding criminal bars, and the need to extend the TPS deadline. Our Clinic students participated in direct conversations and written communication with the USCIS Director, Alejandro Mayorkas, regarding the problems facing Haitian TPS applicants, focusing primarily on fee waiver and extension issues. Because our Clinic students had the experience of filling out and advocating for so many fee waivers they had expertise regarding the difficulties and barriers many persons in this particular population faced in terms of proving their inability to pay. ${ }^{65}$ Some of the students' successes as policy advocates in this matter resulted from their firsthand knowledge and experience applying for fee waivers on behalf of TPS applicants, some of whom lived, for example, in homes with dirt floors and a single light bulb. Despite the client's extreme poverty, many of these clients lacked documentation that USCIS often required to demonstrate they were poor and therefore fee waiver eligible.

We successfully advocated for USCIS to alter and clarify its waiver policy as well as notify and re-train USCIS employees who were incorrectly adjudicating fee waivers. The national TPS fee waiver approval rate went from $55 \%$ to $87 \%$ by April of $2010 .{ }^{66}$ Many of the consortiums' other policy goals were achieved, including extension of the initial TPS filing deadline to January 18 , $2011 .^{67}$

${ }^{65}$ Our students used our template intake forms to assist them in recognizing those individuals who were eligible for a fee waiver. We applied for fee waivers for over ninety of our clients and $100 \%$ of our fee waivers were approved. Internal University of Miami Health \& Elder Law Clinic intake forms and spreadsheet, Haitian TPS Cases - Fee Waivers (Jan. 14, 2010) (on file with authors).

${ }^{66}$ Telephone conference call with U.S. Citizenship and Immigration Serv. (May 19, 2010) (notes on file with authors).

${ }^{67}$ Extension of the Initial Registration Period for Haitians under the Temporary Protected Status Program, 75 Fed. Reg. 39957 (July 13, 2010). 


\section{E. TPS Monitoring Project}

Initially, the Clinic hoped to complete the TPS project by May 2010. Once we realized this was impossible, we instituted the Summer TPS project with three part-time law students and two attorneys to follow-up on and monitor the cases. This project continued into the fall semester 2010 and two Clinical Fellows managed ongoing maintenance throughout the fall.

The biggest obstacle has been responding to Requests for Evidence (RFEs) that require rapid responses. ${ }^{68}$ In order to respond to RFEs, the students had to promptly figure out what evidence USCIS wanted, how to get it from the client, and how to submit it timely to USCIS. Many of the TPS applicants were homeless, had moved, or did not speak English. Even those clients that the students could find and communicate with oftentimes did not have the specific documentation USCIS was requesting, and did not know how to get it. Therefore, the students would end up on a scavenger hunt for the required documents. Sometimes unexpected eligibility issues arose that students dealt with on a case-by-case basis. To date, we are still receiving RFEs from USCIS.

In order to streamline our RFE responses we created RFE templates, packets, and held weekly TPS case review meetings. We created a template cover letter for some of the most common RFEs: Haitian nationality, presence prior to the earthquake and continuous presence and residence in the U.S., criminal history, and communicable disease verification. Similar to our TPS application packets, each RFE packet was identical. The USCIS blue RFE sheet went first followed by our cover letter and notice of appearance. Each piece of evidence had a separate yellow coversheet explaining what the document was and what it established. The attorneys would

${ }^{68}$ At first, in January and February, USCIS gave very short time frames for advocates to respond to RFEs-some as short as fifteen days. Then, due to the consortiums' dialogue and advocacy with USCIS, the response times became much longer and USCIS provided between thirty and sixty days to respond to RFEs. Internal University of Miami Health \& Elder Law Clinic files (Jan. and Feb., 2010) (on file with authors). 
review each RFE packet for completeness and accuracy before the students sent them out via express mail in USCIS' specially designated RFE envelope. This process enabled law students to effectively respond to each RFE in a complete and timely fashion. While the application follow-up was more time consuming than we had ever imagined, it was an extremely important aspect of representing this vulnerable population because most of the applicants would have been unable to adequately respond by themselves and would have been denied TPS.

\section{Lessons Learned}

\section{A. Time Was of the Essence}

Being first legal responders was a critical element of the success of the mass TPS intake project. In Haiti, when the earthquake hit, victims were looking for immediate disaster and medical relief. The first responders in Haiti provided on the scene rescue service, medical care, food, and water. In the United States, and specifically Miami, once TPS was granted, Haitians whose family and friends had been affected by the earthquake in one way or another sought and needed immediate legal relief. ${ }^{69}$ Many Haitians in South Florida did not have work authorization and therefore could not send remittances to family members in Haiti who needed emergency funds to cope with the devastating effect of the earthquake. The sooner they applied for TPS, the sooner they would have employment authorization documents, the sooner they could secure employment and send much needed monetary relief to Haiti. Haitians in Miami were gathering documents and preparing to apply for TPS even before it was officially designated in order to be first applicants and avoid cumbersome and long processing times.

${ }^{69}$ The immediacy of need for legal help post disaster is a recurring theme and a crucial element of the legal "first responder" model. For example, persons affected by a hurricane or an earthquake in the U.S. will need legal help securing emergency shelter and emergency Food Stamps. 
A rapid response was also important because the Haitian community has often been targeted by unscrupulous immigration providers who surface in the community as soon as potential immigration benefits are available and charge higher than necessary fees for low-quality, frivolous, and often erroneous immigration applications. ${ }^{70}$ Sometimes these applications are never filed at all. Other times, fraudulent immigration providers do so much damage to a victim's file or status that the individual permanently loses the opportunity to pursue immigration relief. ${ }^{71}$ There was grave and widespread concern that such individuals and organizations would target members of the Haitian community anxious to obtain TPS. ${ }^{72}$

Immediacy delivers victims and volunteers. A rapid response to the disaster was essential to harness and channel the energy of both the victims and the responders. When TPS was first announced, legal service providers were overwhelmed with the number of people who wanted to apply. ${ }^{73}$ Non-profit providers wanted to assist applicants in a fast and organized capacity as rumors circulated that hundreds of thousands of Haitians would apply for TPS, without severely limiting the services they already provided. Volunteer hotline numbers rang off the hook with persons who were willing to help. This initial surge only happens immediately post-disaster and inevitably dies down even though the need still exists. ${ }^{74}$ Rapidity of

${ }^{70}$ Billy Shields, The Murky World of Notarios, Miami DalLY Bus. REV., July 20, 2009, at A10.

${ }^{71}$ Fight Notario Fraud, ABA, http://new.abanet.org/Immigration/Pages/ FightNotarioFraud.aspx (last visited May 11, 2011).

${ }^{72}$ See, e.g., USCIS Warns of Immigration Scams Targeting Haitian Applicants, U.S. CITIZENSHIP AND IMMIGR. SERVS., http://www.uscis.gov/portal/site/usci s/menuitem.5af9bb95919f35e66f614176543f6d la/?vgnextoid=d183f9a7a96662 10 VgnVCM100000082ca60aRCRD\&vgnextchannel=1 c087bc37b027210VgnVCM1 00000082ca60aRCRD (last visited May 11, 2011); John Pacenti, Undocumented Haitians Likely Targets of Fraud, MIAMI DAILY BUS. REV., Jan. 25, 2010, at A1.

${ }^{73}$ Alexia Campbell, 'We were besieged': More than 1,000 South Florida Haitians apply to stay in U.S for 18 months, SOUTH FLA. SUN-SENTINEL, Jan. 28, 2010.

${ }^{74}$ Kaye, supra note 13, at 907 ("It is unfortunate to note that although many needs continue to exist, the rush of legal volunteers has diminished."). 
response has also been linked to better long-term outcomes in recovering from the psychological damage of a disaster. ${ }^{75}$

We also took into consideration that USCIS might be affected by immediacy, and that its focus on and empathy to Haitians would likely be highest in the immediate aftermath of the earthquake. We thus sought to assist as many people as possible in receiving TPS approval and employment authorization as quickly as possible in order to take full advantage of what we perceived to be a possibly brief window of opportunity fueled by compassion.

\section{B. Organization is Essential and Technology is Helpful}

Case management systems - whether electronic or paperbased - are essential. Our Clinic uses the commercially available Amicus Attorney practice management software system. ${ }^{76}$ In order to manage our new TPS caseload, our legal assistant added each TPS case into our Amicus database and they became part of our caseload. We also created two separate TPS spreadsheets. The first was a complete list of every TPS case and the current status. The second was the TPS to-do list with a running listing of cases with deadlines to be met. Once we received an RFE from USCIS with a due date, we listed the case on the to-do list with the name of the law student responsible for completing the task. A case would remain on the todo list until TPS was approved by USCIS and would always remain on the complete TPS list. We held weekly TPS case review meetings for a year to monitor due dates and make sure nothing fell through the cracks. We also used the complete master list to make sure that USCIS timely processed and adjudicated the cases. If the case fell outside the normal USCIS processing times, we placed it on the todo list and contacted USCIS for a service request.

We kept our paper TPS case files separate from our active

${ }^{75}$ Peter E. Hodgkinson \& Michael Stewart, Coping With CATASTROPHE 111 (2d ed. 1998).

${ }^{76}$ AMICUS ATTORNEY WEBSITE, http://www.amicusattorney.com/ (last visited May 11, 2011). 
Clinic cases. We created a filing system with banker's boxes organizing cases alphabetically and by status. As cases moved from pending to approved they moved into a different box. This electronic and physical case management system enabled us to monitor, organize and triage all the cases, and delegate time-sensitive tasks to law students. Keeping the files in the portable banker's boxes facilitated our work, as the boxes with the relevant and active files could be taken easily to community centers and to internal meetings wherever and whenever they were needed.

Overall, we would have benefited from a more nimble electronic case management system, or one with a more flexible database component. We ended up doing too much of the listing and organizing work manually with an Excel spreadsheet. Formgenerating software would have expedited some of our work and made the review process less taxing. A portable electronic or paperless scanning and filing system would have eliminated the need for carting the bankers' boxes everywhere, though none of these bells and whistles is required to provide the services.

\section{Assisting Vulnerable Populations Presents Special Challenges}

The fact that disasters often impact vulnerable populations (those who are impoverished, of advanced or young age, who have language barriers, or significant medical conditions) more harshly than the general population is well-documented. ${ }^{77}$ Disasters often

${ }^{77}$ Mary Jo Gibson \& Michele Hayunga, We Can Do Better, AARP PUBLIC POLICY INST. 1 (2006), http://assets.aarp.org/rgcenter/il/better.pdf; Planning for a Pandemic/Epidemic Disaster: Caring for Persons with Cognitive Impairment, AM. HEALTH CARE ASS'N, http://www.ahcancal.org/facility_operations/disaster_plan ning/Documents/pandemic_dementia_care.pdf (last visited May 11, 2011); William F. Benson, CDC's Disaster Planning Goal: Protect Vulnerable Older Adults, CENTERS FOR DISEASE CONT. \& PREV., http://www.cdc.gov/aging/pdf/ disaster_planning_goal.pdf (last visited May 11, 2011); Arthur Cooper, Vulnerable Populations in Disasters: Health Effects and Needs, NAT'L. CTR. FOR BIOTECHNOLOGY INFO., http:/www.ncbi.nlm.nih.gov/books/NBK32854/ (June 1011, 2009); Alice Fothergill, Enrique G. M. Maestas \& JoAnne DeRouen Darlington, Race, Ethnicity and Disasters in the United States: A Review of the Literature, 23 DISASTERS 156, 156-173 (1999). 
exacerbate the fissures and inequities that already exist in a community. Where there is already an ongoing need for relief and free legal services, a disaster only heightens the need. Often, the preexisting problems that vulnerable populations experience in accessing the legal and public benefits systems are made many times worse when other groups that were not in need of relief begin competing for access to those same programs.

Many of our TPS clients, like most of our regular Clinic clients, were extremely impoverished and not proficient in English. Some had cognitive impairments, were of advanced age, and were managing serious chronic medical conditions. Many had no phones. Some were homeless with no reliable address. Communicating with the clients was a challenge under the best of circumstances, and we quickly exhausted and overtaxed our Haitian Creole speaking students. Community contacts here were vital. Volunteers who were committed to helping this segment of their community made it possible for us to communicate with clients who otherwise would not have been able to access our services. In order to ensure that we did not run afoul of ethical norms in utilizing volunteer interpreters we developed a training module for the law students and the volunteers that addressed confidentiality and privilege. While we think we covered this adequately, if we were planning for a future campaign like this we would do a better job of systematizing this training module, and would have written materials to hand out from day one on these topics.

Because many of our clients had no phone and some had no address, it was easy to lose contact with them, and students had to be dispatched on a regular basis to search for them in shelters, at their last known address, and among relatives and friends. This was particularly nerve-wracking as we were up against tight deadlines for responding to RFEs, and mounting a search in the community for clients is extremely time-consuming. In retrospect, we should have established and implemented a regular monthly "check-in" system with clients who did not have reliable addresses and telephone numbers. We have used such a system with our regular Clinic clients and it has worked well. 


\section{Financial Resources are Critical}

Although not everything can be solved with money, solutions are impossible to access without financial resources, even when you are working with volunteer labor. We are immensely grateful to the University of Miami School of Law, which underwrote all of the Clinic's costs in running this project - the supplies, the food for the volunteers, the endless number of express mailings that are required as a part of the application and RFE response process, local travel costs and more. The students who rotated through our Clinic for their alternative spring breaks had additional travel and lodging expenses and they had to rely on their law schools, and ad hoc fundraising to meet those expenses.

There were no funds available for us or for the volunteer students to support this important work. The organized bar responses centered on donating to charitable relief work such as the Red Cross, asking lawyers to donate time, and funding existing legal service providers. ${ }^{78}$ Despite the enormous success of the Equal Justice Works funding for law students assisting post-Katrina, ${ }^{79}$ the message that there should be ongoing structural support for law students responding to disasters has not been internalized by the organized bar. We hope that this paper will help to persuade the legal community to consider mechanisms to support this work in the future.

${ }^{78}$ See, e.g., Statement of Carolyn B. Lamm, President, American Bar Association Re: Haiti (Jan. 14, 2010), http://www.abanow.org/2010/01/statementof-carolyn-b-lamm-president-american-bar-association-re-haiti/ (urging members of the bar to donate to organizations such as the American Red Cross, the United Nations Children's Fund, Doctors Without Borders, and others); Memorandum from Paul Doyle, The Florida Bar Foundation on the establishment of an "Emergency Haitian Temporary Protected Status Project" to the Legal Assistance for the Poor/Law Student Assistance Grant Committee (Feb. 5, 2010), http://www.abanet.org/disaster/pdfs/emergency_haitian_temporary_protected_stat us_project.pdf (providing funds to existing legal services grantees).

${ }^{79}$ See supra Sec. I. 


\section{E. Leveraging Legal Resources with Troops of Law Students Works}

"Many hands make light work." ${ }^{\circ 0}$ Being legal first responders was an easy way to harness the energy, talents, and compassion of a large number of law students in a short period of time. First response will almost always heavily emphasize the provision of direct services to individuals affected by a disaster and utilizing law students is an incredibly effective way to leverage scarce legal resources. ${ }^{81}$ The tasks described above could never have been accomplished without the critical mass of law students who volunteered their time. The work the students performed was not only successful from a legal service delivery standpoint; it also was a professionally satisfying and educational experience for the law students who participated.

The large number of law schools and students from around the country wanting to help following the TPS designation was inspiring. ${ }^{82}$ Many of the students who participated in this response have expressed their appreciation of the opportunity to contribute in this manner. ${ }^{83}$ In just a week, students learned a great deal about how

${ }^{80}$ John Heywood, The Proverbs and EPIGrams of John HeywoOd 167 (Spenser Society 1867) (A.D.1562).

${ }^{81}$ Duong \& Choi, supra note 33, at 26; Kaye, supra note 13, at 56-57.

${ }^{82}$ UM Law Hosts Alternative Spring Breaks UNIV.OF MIAMI SCHOOL OF LAw, (Feb. 10, 2010), http://www.law.miami.edu/news.php?article=1460 (quoting clinical instructor Melissa Swain).

${ }^{83}$ Sean Hassan, Day Four \& Five - Final Stages, UM LAw Alternative SPRING BREAK - HAITIAN TPS (Mar. 27, 2010), http://umlawalternativespring break.blogspot.com/; Jennifer Holmes, Day Three: A Tough Case, UM LAW ALTERNATIVE SPRING BREAK - HAITIAN TPS (Mar. 24, 2010), http://umlawalter nativespringbreak.blogspot.com/; Dana Isaac, How Quickly Time Passes, UM LAW ALTERNATIVE SPRING BREAK - HAITIAN TPS, http://umlawalternativespringbreak. blogspot.com/ (last visited May 17, 2011); Katie Plichta, Day One: Training and Community Outreach in Little Haiti, UM LAW ALTERNATIVE SPRING BREAK HAITIAN TPS (Mar. 22, 2010), http://umlawalternativespringbreak.blogspot.com/; Atina Rizk, Final Push, UM Law Alternative Spring BreaK - Haitian TPS (Mar. 12, 2010), http://umlawalternativespringbreak.blogspot.com/; Carolyn Slauson-Ali, Day Two: All Hands on Deck, UM LAw AlTERnATIVE SPRING BREAK - HAITIAN TPS (Mar. 23, 2010), http://umlawalternativespringbreak. 
to work with government agencies and about immigration law. ${ }^{84}$ While many were surprised by the amount of outreach work they did, ${ }^{85}$ the experience was a valuable lesson in client relationship building, communications skills, and client advocacy. ${ }^{86}$ Students were particularly touched by some of the stories they heard from clients they attempted to help. They also expressed their frustration with the system when, in some cases, TPS would not assist some of those they interviewed. This gave students the opportunity to do more research to find solutions beyond TPS that would truly assist the individuals they encountered. ${ }^{87}$

Law students are not limited to direct representation of clients to respond to the legal needs of a community post emergency or natural disaster. As discussed above, ${ }^{88}$ as time went by, and the crush of immediate need for direct services lessened, our Clinic students identified systemic issues and problematic patterns in USCIS's processing of TPS applications, particularly those seeking fee waivers. The students were able to use their experience and firsthand knowledge to advocate for policy changes that benefited the

blogspot.com/.

${ }^{84}$ Hassan, supra note 83; Rizk, supra note 83.

${ }^{85}$ Isaac, supra note 83; Plichta, supra note 83 ("[E]ach of us realized that TPS is not as widely known amount the Haitian community as we originally believed."); Isaac, supra note 83 ("I don't think any of us expected to do the amount of outreach that we did, and I don't think we expected our clients to have been living in the United States for as long as they had... ").

${ }^{86}$ Hassan, supra note 83 ; Holmes, supra note 83 ("Without any documents or few common language skills among us, the interview was very difficult."); Isaac, supra note 83; Rizk, supra note 83 ("We learned ... how to communicate with clients in an appropriate manner.").

${ }^{87}$ Many students were particularly touched by a father and son who had arrived following the earthquake. The son, ill with leukemia, was sent to Miami from Haiti to receive medical treatment. Because of the timing, the father and son did not qualify for TPS, but students, working with the Clinic attorneys, described the humanitarian parole process, and put them in touch with the appropriate program to pursue this option. Hassan, supra note 83; Holmes, supra note 83.

${ }^{88}$ See supra Sec. II.D. 
affected community. ${ }^{89}$ Law students have been similarly involved in the Gulf doing impact litigation as well as policy advocacy. ${ }^{90}$ This is the way policy advocacy should happen - from the bottom up. This approach to policy advocacy is desirable because agencies want examples from providers of how current policy is problematic before instituting systemic changes. Students working as the legal troops on the ground can help the government agencies tailor their policies to effectuate their goals and help the target population to more easily access the disaster benefits. Disaster preparation can include both short-term representation of individuals as well as the longitudinal and systemic issues, which may only be resolved via policy advocacy with the agencies in charge. This aspect of our TPS project will remain active long after most, if not all, of our individual TPS cases are adjudicated.

\section{F. Responding to Disasters Has a Huge Opportunity Cost}

One of the first casualties for our Clinic was any semblance of normalcy. We had enormous difficulty scheduling time for reflective learning, a hallmark of clinical pedagogy. The Health and Elder Law Clinic is high-volume by design, with over 150 active cases at any given time, making case and docket management a difficult yet essential component of our work. Adding 150 TPS cases made docket management an almost overwhelming challenge. Upon reflection, this undertaking was probably too much to add to a Clinic with an existing caseload of over 150 cases. A year later, we are still feeling repercussions. The time commitment and energy required to maintain the TPS Project along with our regular caseload has restricted our Clinic's intake capabilities. The Clinic had to stop weekly intakes of new clients in the fall semester and instead created a waitlist for prospective clients. A year later, we have finally

${ }^{89}$ Letter from JoNel Newman, Associate Clinical Professor and Director, Health and Elder Law Clinic, University of Miami School of Law to the Department of Homeland Security (Sept. 13, 2010) (on file with authors) (students and clinical professors requested modifications to the fee waiver process and provided a model updated Fee Waiver Form).

${ }^{90}$ E-mail from Davida Finger, supra note 28. 
reopened our general intake and still have a weekly meeting devoted to pending TPS cases. One of our Clinical Fellows, Matthew Eandi, still devotes the majority of his time to ongoing TPS matters. Our legal assistant is also taxed with monitoring the cases that are still pending and have not yet been processed by USCIS.

Any lawyer, law student, or clinician embarking on a first response legal service delivery project should also keep in mind the very real possibility that responders may develop or suffer from secondary trauma or compassion fatigue. ${ }^{91}$ Because our Clinic's regular caseload consists of a high number of clients in emotional distress, we try to incorporate some training in this area for our Clinic students. During the TPS Project, it was challenging to cover this in any meaningful way with the large numbers of volunteers who were constantly changing since our focus was to provide legal services as quickly and competently as possible, and we frankly did not think of this until after the fact when we saw upset students. We recommend developing or borrowing materials, ${ }^{92}$ and incorporating them into the first training for volunteers, even if this consists only of a handout that volunteers can review at their leisure.

Another casualty was that we abandoned our holistic representation model for the Haitians we helped with TPS. Our philosophy dictates that we do not provide self-help or advice-only services to clients, but instead represent and file a notice of appearance in all of the client's legal matters that fall within the scope of our Clinic's capabilities. Our TPS project was a casualty of emergency - an exception to our policy - in which we offered clients a limited retainer to represent them only in TPS.

${ }^{91}$ Charles R. Figley, Compassion Fatigue as Secondary Traumatic Stress Disorder: An Overview, in COMPASSION FATIGUE 1 (Figley, ed. 1995) (describing this disorder).

92 See, e.g., Janice Mucalov, Lawyers: Gatekeepers for Psychological Issues, CANADIAN BAR ASS'N NAT'L MAG., http://www.cba.org/cba/practicelink/career builders_clients/psych.aspx (last visited May 11, 2011) (offering suggestions to assist lawyers to protect themselves when they work with clients under stress and to help them recognize the symptoms of vicarious trauma). 
Even though our scope of client representation in this instance was limited to TPS, we did not just fill out applications. We entered an appearance in every TPS case and worked on the case throughout the adjudication process because our theory was that clients would be unable to navigate the rest of the application process on their own and a high percentage would ultimately be denied. While we believe that our success rate ${ }^{93}$ (and the fact that we can even track it) proves the efficacy of this model, it has prevented us from doing a great many other things. It is for these reasons that we urge our colleagues to think about institutionalizing this capacity in the ways that follow.

\section{Recommendations for Law Schools and Conclusion}

In the past, law schools and clinics have created and managed disaster projects in addition to their existing programs on an ad hoc and as needed basis. ${ }^{94}$ Based on our experience, we caution against the continuation of this approach. Instead, we are convinced that the time has come for law schools to deliberately and intentionally build disaster preparedness programs, courses and clinics into their curriculum pre-disaster based on a legal first responder model. ${ }^{95}$

${ }^{93}$ See Obtaining TPS, supra note 47.

${ }^{94}$ Balancing Civil Liberties \& National Security After September 11 Clinic, YALE LAW SCHOOL, http://www.law.yale.edu/academics/BalancingCivilLiberties .htm (last visited May 11, 2011); A Rights-Based Approach to Combating Poverty: Economic, Social \& Cultural Rights, BERKELEY LAw, http://www.law.berkeley. edu/2982.htm (scroll to "The 2004 Tsunami and Human Rights") (last visited May 11, 2011) (explaining how clinic students contributed to study of issues plaguing tsunami victims); Legal Help for Flood Victims, NASHVILLE Pro Bono (May 4, 2010), http://nashvilleprobono.wordpress.com/2010/05/04/legal-help-for-floodvictims/; Twenty Florida Lawyers Honored for Providing Free Legal Services to the Poor, THE FLA. BAR (Feb. 16, 2006), http://www.floridabar.org/TFB/TFB Public.nsf/WNewsReleases/5238464ED67C7DA685257116004C567B?OpenDocu ment (naming recipients of The Florida Bar President's Pro Bono Service Award such as Michael Stebbins of Pensacola who was honored for pro bono efforts at a clinic offering free legal aid to hurricane victims in 2004 and 2005).

${ }^{95}$ See Lash \& Morse, supra note 10, at 899 (suggesting legal communities, including legal practitioners and law schools create committees for disaster 
Creating a legal first responder corps will allow law students to practice during training, to help community members with current legal problems, and to respond to the community's legal needs during and post-disaster. We suggest that law schools and students change the current ad hoc approach to emergency response, and that instead we train law students to become legal first responders, that we expand the law school's service delivery model to include disaster response and relief, that we create a law school disaster relief network, and that we incorporate this legal corps into the larger community pre-disaster.

We recognize that real efforts have been made by the legal community to respond to disasters. Our recommendations are intended to supplement what has already been accomplished with respect to the legal academy. We set forth below several alternative possibilities for the law schools to consider.

\section{A. Develop a Disaster Preparedness Clinic}

As legal educators, clinicians, and legal service providers with a social justice agenda, we are concerned with developing clinical programs that secure relief for basic human needs. We believe that a disaster preparedness clinic could undertake this work pre-disaster while preparing to respond to the immediate and long term needs of disaster victims. Law schools should give consideration to developing a disaster preparedness clinic. Many law schools have created clinics focusing on emergencies after they occurred. For example, the University of California at Berkeley Law School developed the Hurricane Katrina and Human Rights Projects to assist with immigration and human rights issues following the 2005 hurricanes affecting the Gulf Coast. ${ }^{96}$ Loyola Law School

preparedness and response); Stephen N. Zack, Disaster Preparedness is Key to Preserving Our Justice System, Says Zack, ABA (Aug. 10, 2010), http://www.aba now. org/2010/08/disaster-preparedness-is-key-to-preserving-our-justice-system/.

${ }^{96}$ The clinic, based on experience with the 2004 tsunami in the Indian Ocean, undertook three initiatives following the 2005 hurricanes affecting the Gulf Coast to: 
created a clinic following the Katrina hurricane to provide victims with information regarding legal issues like child custody and insurance issues. ${ }^{97}$ Yale Law School created a clinic for students to assist clients with civil liberties issues following governmental implementation of new policies after September 11, 2001. ${ }^{98}$ Our question is - why not institutionalize such clinics before disaster strikes?

Disaster preparedness clinics could be a significant addition to clinical legal education while providing legal armies with the practical skills to assist disaster victims. Students in such a clinic could secure basic human needs and rights for a community predisaster and then replicate this service during and post-disaster. Those interested in starting and participating in a disaster clinic should not be discouraged by the uncertainty of when and if a disaster will strike and should keep in mind that there are both immediate and long-term disaster relief efforts in which students can participate.

\section{Everyday Emergencies}

Law students, under the supervision of clinicians, can represent low-income persons in many different legal practice areas such as public benefits, disaster assistance, landlord/tenant, foreclosure, consumer issues, insurance claims, and permanency planning. ${ }^{99}$ These legal practice areas present everyday emergencies

(1) provide new information about the experience of immigrantsdocumented and undocumented-in the wake of hurricanes; (2) engage human rights mechanisms to highlight and strengthen human rights protections of hurricane survivors; and (3) promote recognition and compliance by US officials with international human rights standards protecting survivors of natural disasters without regard to their legal status.

BERKELEY LAW, supra note 94.

${ }^{97}$ Pro Bono Opportunities, supra note 27.

98 Balancing Civil Liberties, supra note 94.

99 A disaster preparedness clinic could include estate planning education and 
to many persons living in poverty that will be exacerbated when disaster strikes. ${ }^{100}$

Clinics should determine in advance what types of disaster relief legal services they will provide. ${ }^{101}$ Law students should collaborate with expert local lawyers and practitioners to learn the specifics of the substantive law as well as practical skills. The law students should also receive clinical training on ethics and professionalism and lawyering skills. Disaster preparedness clinics should form a national network to, among other things, make these trainings available online and via podcast to share with other law schools. ${ }^{102}$ Students in a disaster preparedness clinic can also create, update, or maintain state and local disaster manuals to ensure that when a disaster hits, the legal community can respond in a coordinated fashion. ${ }^{103}$

\section{Community Connections}

A disaster preparedness clinic should strive to create and maintain relationships with the communities they serve. The law students should develop their potential client base through community outreach, needs assessments, and know your rights

service work. Wills, durable power of attorney, health care surrogates, living wills, do-not-resuscitate orders, preneed guardianships, and funeral directions could be completed to help a community prepare for disaster.

${ }^{100}$ We believe that the term "emergency" can apply not only to situations following a natural or man-made disaster. A family in which the primary wageearner has been diagnosed with a terminal illness, a family where children are malnourished due to poverty, an individual in a homeless shelter attempting to appeal a disability denial, or a family facing eviction are examples of situations where people are facing an emergency that requires legal assistance.

${ }^{101}$ Though it is possible to predict some important disaster clinic practice areas, we caution that the substantive law may change. Students should be prepared to respond to unexpected legal practice areas that were not anticipated. They should be prepared to adapt.

102 See Obtaining TPS supra note 47.

${ }^{103}$ See Florida's Legal Assistance Disaster Manual, supra note 18, Sec. VII at 2 . 
presentations. ${ }^{104}$ The Florida Disaster Legal Assistance Manual recommends developing familiarity with mass service distribution sites and isolated communities, and maintaining a regular presence at these sites. ${ }^{105}$ Law students should do the same by going community by community, block by block, street by street, house by house, shelter by shelter and helping people apply for benefits pre and post disaster. Law students could develop a disaster intake packet to screen potential applicants, attend regional and/or statewide trainings, and do mock interviews to practice client interviewing and counseling. They can locate and visit Disaster Recovery Centers (DRCs) and determine whether they are working effectively to meet the needs of the community. Law students can help to widely disseminate information to the community by visiting homeless shelters, mass feeding sites, DRCs, community agencies, and churches $^{106}$ to discuss available benefits and legal assistance. Law students can also build relationships with local community leaders and distribute information in local restaurants, stores, commercial plazas, strip malls, barbershops, and on local cable, community radio stations and newspapers. In theory, educating people pre-disaster will minimize the burden of disseminating information when the disaster hits because advocates will be dealing with an informed population who is more prepared for a disaster and/or emergency and knows what to expect and where to turn for help.

\section{Emergency Food Stamps}

We propose that students in a disaster preparedness clinic practice with an emergency Food Stamps project by conducting

${ }^{104}$ The importance of community connections and trust to the success of any of this work cannot be overstated. See Anthony A. Alfieri, Faith in Community: Representing "Colored Town," 95 CALIF. L. REV. 1829 (2007) (exploring raceconsciousness and community lawyering efforts); Gerald P. López, Reconceiving Civil Rights Practice: Seven Weeks in the Life of a Rebellious Collaboration, 77 GEO. L. J. 1603 (1989).

${ }^{105}$ See Florida's Legal Assistance Disaster Manual, supra note 18, Sec. VII at 11 .

${ }^{106}$ See id. at 10. 
intakes drives in the community and then processing client applications. This will afford the clinic an opportunity to develop a routinized, systematic practice. The eligibility rules for emergency Food Stamps are quite simple, but people are often unaware this emergency benefit exists and are unable able to obtain it without legal representation. To be successful, law students would have to educate community members as to the availability and eligibility criteria for this benefit, interview potential applicants, acquire and produce verification of eligibility, fill out applications, and negotiate with the state agency administrating the food stamp program. This exercise has the potential to providing many low-income community members with immediate relief. ${ }^{107}$ This exercise will prepare the clinic students for assisting victims of the next disaster apply for and acquire government public benefits. ${ }^{108}$

${ }^{107}$ The use of technology has the potential of making this a less daunting challenge for the law students and delivers more rapid assistance to the community in need. In order to provide immediate relief during a disaster, law students could submit expedited, disaster and replacement food stamp applications online on behalf of clients. One could imagine law students equipped with laptops and internet access filling out food stamp applications for people at their front door. We would warn, however, that students seem very comfortable with technology and that in a time of a disaster they may not have access to much technology if any at all and may have to resort back to an "old school" approach. Therefore, students should be trained in electronic and paper versions of applications.

108 The emergency, sometimes called expedited, and disaster-related Food Stamp programs often have minimized verification or eligibility standards and provide short-term relief following a disaster or to meet critical nutrition needs while full eligibility verification is processed. See, e.g., An Advocate's Guide to the Disaster Food Stamp Program, FOOD RESEARCH \& ACTION CTR.,7 (July 2005), http://www.frac.org/pdf/dfspguide06.pdf; Application Processing: Policy Manual, FLA. DEP'T OF CHILDREN \& FAMILIES $\$ 0610.0102$, available at $\mathrm{http} / /$ www.dcf.state.fl.us/programs/access/docs/esspolicymanual/600.pdf (last visited May 11, 2011) (citing process for Expedited Services of Food Stamps); Food for Florida, FLA. DEP'T OF CHILDREN \& FAMILIES, http://www.dcf.state.fl. us/programs/access/fff/docs/GeneralEligibilityRequirements.pdf (last visited May 11,2011 ) (providing a form describing disaster relief foods stamps eligibility). Both are services that individuals might not be aware they qualify for and provide for relatively quick approval timeframes, making the exercise a confidence builder for the student and an opportunity to build trust with the client. 
Another reason we recommend the emergency Food Stamp project is because the entire process can be accomplished in one week. We have found that a clinic can become very efficient and effective if everyone is working on the same thing at the same time. For example, students could all be trained on the first day, educate and interview potential food stamp applicants the next day, complete and file the applications on the third day, follow up with verification and advocacy on the next day and acquire the public benefits for the applicant on the last day. During a full semester, a clinic could conceivably have several week-long service projects that they are able to complete in different communities or neighborhoods.

Students can transfer the skills learned in the Food Stamps project to disaster-specific benefits such as IHP Housing Assistance and other FEMA related benefits on an expedited basis. Students can follow up on applications, appeal denials and insufficient awards, and recoupment.

\section{Chronicling and Sharing Accomplishments}

A disaster clinic should keep track of its goals and accomplishments. A database of clients should be developed to track outcomes empirically. The students' experiences should be discussed through weekly case rounds, reflection, blogging, or journaling. After the service project is complete, the students should write a handbook or manual for distribution to clinics nationwide describing what worked, the challenges they faced and the lessons learned. This information is essential for other clinics and law students who may still be in the planning, developing, training, or practicing stage and have not yet faced a disaster.

\section{Creating Capacity}

Law schools and clinicians located in regions that are likely to be plagued by disasters should assess whether their existing 
clinical programs have capacity to include disaster relief work. If not, ${ }^{109}$ we recommend giving serious consideration to developing a separate clinic or program devoted to disaster planning, relief and recovery. Clinical legal education should intentionally and deliberately expand its service delivery model to include emergency and disaster relief. As we hope has been demonstrated above, ${ }^{110}$ this type of clinic can be consistent with sound clinical pedagogy and can create practice-ready law students while serving the community.

\section{B. Alternative Breaks}

Law schools could develop disaster preparedness projects during any break period. ${ }^{111}$ Similar to a disaster preparedness clinic, we caution that alternative break projects should not happen on an ad hoc basis, but instead should be institutionalized at host schools as a year-round law school program. This model provides the community with expedited access to legal help while giving students the opportunity to acquire legal skills on their journey to become practice ready. We suggest that the alternative break projects use the TPS or emergency Food Stamp models described above. Students can do online trainings to become familiar with terms and concepts before they arrive. Students will still need to be trained in substantive law, lawyering skills, ethics, and professionalism on site.

${ }^{109}$ See supra Sec. IV, A.

${ }^{110}$ See supra Sec. II.C.

111 Jill Goetz, Second GGU Group Goes to New Orleans to Assist Victims of Hurricane Katrina, GOLDEN GATE LAw., Spring/Summer 2007, at 6, http://www. ggu.edu/school_of_law/law_alumni_services/attachment/Read +the+current+issue. pdf (several Golden Gate University law students spent their spring breaks in 2006 and 2007 offering legal and other aid to Hurricane Katrina victims in coordination with Common Ground Relief); COMmON GROUND RELIEF, http://www.common ground relief.org/ (last visited May 11, 2011) (non-profit organization that offers legal services to assist hurricane victims in New Orleans); Jennifer Epstein, Spring Break in a Disaster Zone, INSIDE HIGHER ED (Mar. 1, 2010), http://www.inside highered.com/news/2010/03/01/haiti; see supra note 58 (schools that worked with University of Miami for the Haitian TPS ASB program). 
One benefit to using this "break" model is that once the host program creates a disaster preparedness training module, they can repeat it throughout the year. Another is that the students are not in classes and can be completely focused on the task at hand. The drawbacks are that the program has high turn-over and there will inevitably be cases to cover and work to be done when one group leaves and before the next one arrives.

\section{Other Law School Service Possibilities}

Different law schools inevitably have different curricular structures and offerings and may house other programs that would be perfectly suited to disaster preparedness. We recommend that law schools consider disaster preparedness and determine where this area fits within their structure. Law schools may choose to offer courses and seminars in disaster law, relief and policy, ${ }^{112}$ allow students to acquire independent study credits for research and writing projects related to disaster preparedness, participate in externships with nonprofit organizations or government agencies that focus on disaster relief, or cover this area through existing pro bono programs. Such offerings not only expand student opportunities for practical experience but also expand the law school's capacity to provide legal services to the community.

112 Golden Gate University School of Law conducted a seminar called the Katrina Seminar in which students' research and writing focused on property issues of those impacted by Hurricane Katrina and criminal issues for the "treatment of elderly and disabled in hospitals and other facilities in the aftermath of Katrina." Professor's Teaching and Scholarship Focus on Katrina's Impact, ENVTL. L. NEwS 3 (Winter 2007), http://www.ggu.edu/school_of_law/academic law_programs/environmental_law_program/newsletter/attachment/ELN-2007Win ter.pdf. Other law schools have conducted seminar courses following disasters in the same tradition. See, e.g., Jen Woods, Law School Profile: Brooklyn Law School, EMPLOYMENTCROSSING: LAWCROSSING, http://www.lawcrossing.com/ article/1916/Brooklyn-Law-School-Brooklyn-NY/ (last visited May 11, 2011) (discussing Brooklyn Law Schools 2002 "Advanced Problems: The Law After 9/11," focusing on the country's legal reaction to the tragedy, including immigration issues). 
D. Recommendations for the Broader Legal Community

Community and legal service providers (non-profit and pro bono) should be cognizant of the tremendous potential law students offer as legal first responders. Law schools and students should be part of any strategic thinking and planning concerning disaster relief. We encourage Bar Associations and law schools to make a conscious effort to collaborate in the area of disaster preparedness and relief. The legal community could greatly improve its disaster response if legal services and non-for-profit legal agencies, bar associations and law schools coordinate pre and post disaster to eliminate duplication of efforts and improve efficiency. 